\title{
Developing Students' Intercultural Communication Competences in Western Etiquette Teaching
}

\author{
Xiaochi Zhang \\ School of Foreign Languages, China West Normal University \\ No.1 Shi Da Street, Nanchong 637000, Sichuan, China \\ Tel: 86-817-256-8519_E-mail: zhangxc66@cwnu.edu.cn
}

\begin{abstract}
How to develop students' intercultural communication competences is a controversial issue in foreign language education in China. In this article, the author attempts to offer an answer to this issue by putting forward a proposition for developing students' intercultural communication competences in western etiquette teaching. First of all, the paper discusses the importance of developing students' intercultural communication competences in western etiquette teaching. Then, the author dwells on the four dimensional approaches to developing students' intercultural communication competences, such as teaching students' basic knowledge of western etiquettes in class and providing more teaching practice opportunities as languages partners, tour guides, all kinds of activities and so on. In this way, we will reach our final goal of foreign language education so that our students will enhance their intercultural communication competences.
\end{abstract}

Keywords: Foreign language education, Etiquette, Western etiquette teaching, Intercultural communication, Intercultural communication competence

\section{Introduction}

Everyone knows people from deferent cultures have their own cultural perceptions, beliefs, values and social customs which greatly determine their communication ways, it is not surprising to find that people have many difficulties and obstacles in understanding one another and communicating with one another. In daily intercultural communications, it is necessary to pay attention to the code that governs the expectations of social behavior, or the conventional norm. These codes required by good breeding and expected to be obeyed are called etiquette. Etiquette is equivalent to protocol, decorum, courtesy, etc. Etiquette today is based on treating everyone with the same degree of kindness and consideration, and it consists mostly of common sense. It is helpful to know some rules about how to behave in certain situations - if only because this makes life more comfortable for you and makes you more self confident in social situation.(Ou, 2008)

Generally speaking, an etiquette is an important integrate part of the whole western culture. And the etiquette teaching is not only taught to know the western social customs, but also structured to enhance self-esteem and character with emphasis on socially acceptable behavior in communicating with foreigners. At the same time, the importance of self-respect and respect for others is taught to give the confidence that is necessary for each student to become self-reliant as he or she communicates with foreigners. Therefore, a western etiquette teaching inevitably involves the teaching of foreign cultures. A foreign language in China, should be regarded not only as a resource for learning foreign cultures but also as a means of intercultural communication. But how should teach western etiquette culture in foreign language education in China? In this article, the author attempts to offer an answer to this question by putting forward a proposition for developing students' intercultural communication competence in the western etiquette teaching. With the discussion of the importance of developing students' intercultural communication competences in the western etiquette teaching, the paper focuses on the four dimensional approaches to developing students' intercultural communication competences in the western etiquette teaching in China.

\section{The importance of developing students' intercultural communication competences in western etiquette teaching}

It is generally acknowledged that language and culture are interdependent, and are closely associated with each other. Culture is rooted in language deeply and language contained rich cultural factors. In the western cultures, different countries have different customs and different etiquettes. And also it will have an influence on personal capacity of intercultural communication. Furthermore, different cultural backgrounds will make a different result of intercultural communication. One cannot hope to have a good command of a target language without adequate knowledge of the culture related to that language. In this sense, acquisition of information about western etiquette is as important as language learning itself. Culture is transmitted through language. In a foreign language teaching, a number of foreign language teachers have a regard only for language knowledge and skills but not for the western cultures, 
especially, the western etiquette which is a important integrate part of the western cultures. This situation makes foreign language and culture out of touch. The western etiquette cultural awareness plays a more and more important role in the cultivation of intercultural communication competence.

\subsection{What is "Intercultural Communication"?}

A British Professor Gillian Brown said, "Communication is a risky business," which means the process of communication is the process of complete interaction. Yet it's not an easy thing to fully communicate because of different histories, cultures, social habits in different peoples (Samovar,2001). Intercultural communication comes primarily out of an interpersonal orientation and addresses the mutual negotiation of social reality among participants. Because of the necessity and reality of inerpersonal aspects of our globalization, we can no longer neglect these aspects of any communication among peoples around the world, whatever problems we may be addressing. Now, intercultural communication comes out of a mass media and political orientation; it addresses information flow between and among nations and other large groups of people. While these areas are constantly in the news and represent the more visible issues confronting us, we must recognize that these concerns subsume the more personal aspects of interpersonal communications (Hill, 2009). Finally, intercultural communication is used when referring to communication between people from different cultures. People have different hobbies and customs because of cultural backgrounds. The diverse habits and customs may cause problems in people's intercultural communication, especially when this intercultural communication takes place between people with distinct cultural backgrounds.

\subsection{Dimensions of intercultural communication competence}

By examining the many dimensions of intercultural communication competence proposed by intercultural communicational scholars, we find that most of the dimensions more or less overlap. Essentially, the dimensions of intercultural communication competence can be defined as four categories: (a) Personal Attributes, (b) Communication Skills, (c) Psychological Adaptation, and (d) Cultural Awareness. Comparing dimensions of communication competence with those of intercultural communication competence, we also see that Personal Attributes indicate the ability to be relaxed in social interaction and the ability to self-disclosure or be open with others, Communication Skills mean the ability to send and receive messages and the ability to demonstrate social skills. Cultural Awareness implies the understanding of environmental varieties. Psychological Adaptation focuses on the ability to handle problems such as frustration, stress, alienation and ambiguity which are caused by cultural differences. Scholars have consistently suggested that only through intercultural communication competence can people from different cultures effectively communicate with each other (Chen, 2010). This definition shows that competent persons must not only know how to interact effectively and appropriately with people and environment, but also know how to fulfill their own communication goals by respecting and affirming the multi-level cultural identities of the interactants. (Chen, 2010)

\subsection{The relation between the intercultural communication competence and western etiquette}

Therefore, students need to learn and understand different western etiquettes in order to improve their intercultural communication competence. No intercultural communication is done without involving some etiquette rules. Etiquettes vary of course from culture to culture. Differences in cultural conventions can lead to difficulties in the communication between peoples with different cultural backgrounds. Such difference can cause misunderstanding, unsatisfactory interaction and even unpleasant physical reactions. Etiquettes are closely related to the deep structure of a culture that determines how a person responds to events and people. Even though what members of particular culture valu e and how they perceive the universe explain a lot why people behave the way they do, we shouldn't try to connect every human behavior with a certain value.

In order to solve the above problem, we are going to suggest that Chinese foreign language educators should focus on developing students' intercultural communication competence which refers to the capability achieved through acquiring knowledge about the western etiquette cultures, and is embedded in language and beyond language, through using this knowledge in the performance of intercultural communication and creating new thinking for a new action. So, we should teach the students' western etiquettes for our broad educational goal. The practice of this proposal indicates students encountering new knowledge, and being exposed to new cultural experiences, which should be related to what is already known and experienced. And then the etiquette teaching is not only taught to know the western social customs, but also structured to enhance self-esteem and character with emphasis on socially acceptable behavior in communicating with foreigners.

\section{How to develop students' intercultural communication competences}

It is undoubtedly that the etiquette will play an important role in intercultural communication. To the definition of 
etiquette, China and the West have different understanding. As Chinese thinks that the etiquette is the common behavior standards that all the members must obey and its purpose is to keep the normal living order of the society (Zhang, 2008). Nowadays, intercultural communication activities increase frequently different cultural factors will be across the collision in the exchange. If you can not master the different western etiquettes, you may have a misunderstanding and conflict in the intercultural communication activities. So, the foreign language educators should know how to develop students' intercultural communication competences.

\subsection{Enhancing western etiquette awareness}

To enhance the western etiquette awareness's training, it is very important for students to accept the teaching of western etiquettes. That is to say, teacher should help students to make a change from ignorance to awareness of the western etiquette culture in class. At the same time, teacher should teach the students not only basic knowledge of western etiquettes, but also cultivate students' social and cultural ability so that they understand the differences between traditional Chinese and western cultures. On one hand lesson combines with authentic materials and takes the students into some social communication factors. On the other hand, teacher should help the students improve their language form and language application in order to get the intercultural sensitivity gradually. Through learning, the students turn externally available knowledge into their own internal knowledge. So, the western etiquette teaching must break the 'just teacher's statement' boring situation, and it should show etiquettes' communication characteristics. Teaching mode would reflect interest, diversity and flexibility. Then teachers can exchange their teaching mode in order to encourage students' learning interest and creative thinking.

\subsection{Learning through different media}

Students can learn the western etiquettes culture through TV and movies and get a vivid picture of what the life of westerners is like in the target culture, because they come to know the truth of native speakers' behaviors. From the observation through the media, the features of everyday situations and etiquettes will impress them such as sightseeing, telephoning, shopping or asking directions. What they have learned from books can be verified by the performance of the native speakers. While enjoying the attractive performance language learners have to observe details of everyday situations in case of greeting, farewell, compliment, apology, requirement and so forth. Through the media, students can learn the polite behavior and etiquette means to solve conflict techniques of practicing intercultural communication and so on. Movies can also improve intercultural communication by conveying the important values, communication styles and so on. After watching movies, students may take notes of their observations, supplement the findings and talk with those who have shared the same movies so that they can apply what they have learned to real intercultural communication someday.

\subsection{Listen to more lectures by foreign teachers}

Students should often attend lectures on culture given by foreign teachers or those who have experiences in foreign countries. Some lectures may be centered on the western cultures while others may be a comparison among different etiquettes. Whichever lecture the students attend it may increase their cultural awareness through the description of different cultures and the techniques for proper behavior in intercultural communication (Liu, 2008). Participating in discussions after the lecture will reinforce the etiquette cultural information they have got from the lecture. What's more such discussions can reveal the relation between different value systems and people's behavior in social activities. In this way, the students will overcome their language and psychological barriers when they communicate with native speakers.

\subsection{Improving communication skills through different activities}

Students can go to English corners, tours, exhibitions to learn etiquettes as a language partner, tour guider or an interpreter. While communicating with people from the other etiquette cultures, students are easily hesitating to speak. When a westerner greets Chinese people, some of them pretend that they have not heard of it or bow their head keeping silent. Some of them smile shyly and quickly go away. All these would make the westerner embarrassed. So students must try to talk to westerners and take advantage of every opportunity to talk with foreign teachers and students available in a relaxed atmosphere(Zhang,2005). They will benefit from such talks since they can not only practice language but also observe native speakers' behavior and exchange their feelings about cultural differences with native speakers. While they should go to all kinds of activities attended by foreign teacher, observation and exchange of feelings are of the same importance. Students should not hesitate to ask foreigners questions concerning cultural differences and foreigners may like to answer them since they are equally eager to know such differences which have much to do with their life in China.

\section{Conclusion}

In conclusion, the idea of developing students' intercultural communication competence in the western etiquette 
teaching is a constructive proposal for how to teach culture in foreign language education in China. To put this idea into practice, the existing curriculums of foreign language teaching must change. Of course, to make change is an arduous task. In this sense, the proposal of intercultural communication competence is just a small contribution we have made in order to bring changes to foreign language education in China. So, the teaching of western etiquette in foreign language education is important to learn and use a foreign language to communicate. It certainly helps us to find some keys to overcome the existing barriers. And it is vital for students to remember that communication is not conducted in a etiquette cultural void, rather it involves too many etiquette differences that may leads to misunderstandings. Therefore, we should be aware of the etiquette differences, show understanding and respect to different etiquettes and most importantly, build bridges across misunderstanding among different etiquette cultures. Overall, the teaching of western etiquettes makes, such an important impact on the students that they carry those knowledge and skills with them into the intercultural communication.

\section{References}

Chen, Guoming. (2010). A Study of Intercultural Communication Competence. Hong Kong: China Review Academic Publishers Limited. pp.7.

Chen, Guoming. (2010). Foundations of Intercultural Communication Competence. Hong Kong: China Review Academic Publishers Limited. pp.26-30.

Hill, L.Brooks. (2009). The future of cross culture communication: Perspectives from 20 years of the IAICS. Intercultural Communication Research. Vol. 1. .83-108.

Liu, Xiaoping. (2008). Intercultural Business Cummication. Tianjing: Nankai University Press. pp.76-77.

Ou Lin. (2008). Western Culture \& Etiquette. Chongqing: Chongqing University Press. pp.3-4.

Samovar, L.A. et al. (2001). Communication between Cultures. Beijing: Foreign Language Education and Research Press. pp.56.

Zhang, Ailing. (2008). Log into the World of Culture. Chongqing: Chongqing University Press. pp.21-36.

Zhang, Guijun. (2005). The Cultural Differences in Cross-cultural Communication. Sino-US English Teaching. vol.12,No.2: 48-52. 